\title{
Short communication: Teat-end shape and udder-level milking characteristics and their associations with machine milking-induced changes in teat tissue condition
}

\author{
M. Wieland, ${ }^{* 1}$ D. V. Nydam, ${ }^{*}$ N. Älveby, $†$ P. Wood, $†$ and P. D. Virkler* \\ *Department of Population Medicine and Diagnostic Sciences, Cornell University, Ithaca, NY 14853 \\ †DeLaval International AB, Tumba 14741, Sweden
}

\begin{abstract}
Machine milking-induced changes in teat tissue condition, such as congestion and edema, have been associated with teat canal openness, penetrability, and thus susceptibility to new intramammary infections and diminished animal well-being. The primary objective of this study was to investigate the association of teat-end shape and machine milking-induced shortterm changes in teat tissue condition. Our secondary objective was to study the association of udder-level milking characteristics and short-term changes. Data from 125 Holstein cows were analyzed in a longitudinal prospective cohort study. Cows were housed in freestall pens with sand bedding, fed a total mixed ration, and milked 3 times per day. Teat-end shape was classified into 3 categories: pointed, flat, and round. Udder-level milking characteristics were obtained from electronic on-farm milk meters. Short-term changes in teat tissue condition after machine milking were assessed visually. Multivariable generalized mixed model analysis showed an association between teat-end shape and short-term changes. Compared with teats with round teat-end shape, the odds ratio (95\% confidence interval) for short-term changes was 1.68 (0.53-5.31) and $0.03(0.004-0.19)$ in teats with pointed and flat teat-end shape, respectively. There was an association between milking characteristics and short-term changes such that higher milk flow rate during the first $15 \mathrm{~s}$ of milking decreased the likelihood of short-term changes. The adjusted probability of short-term changes for a milking observation of a mid-lactation cow and an average first 15 -s milk flow rate of 0.5 and $1.5 \mathrm{~kg} / \mathrm{min}$ was $53.0 \%(42.8-63.8)$ and $32.9 \%$ (15.2-57.3), respectively. Our results suggest that teat-end shape may be one of the risk factors that contribute to machine milking-induced short-term changes. Milking characteristics (e.g.,
\end{abstract}

Received May 13, 2018.

Accepted August 23, 2018.

${ }^{1}$ Corresponding author: mjw248@cornell.edu first 15-s milk flow rate) may have the potential as a measure to indirectly monitor teat tissue changes associated with machine milking on a daily basis, though further research is needed to validate this hypothesis and to establish thresholds that could serve as on-farm guidelines.

Key words: teat-end shape, teat congestion, teat edema, milking characteristics

\section{Short Communication}

Mechanical forces during machine milking affect changes in teat tissue condition (Neijenhuis et al., 2001; Guarín and Ruegg, 2016; Penry et al., 2017b) that are differentiated into long-term, medium-term, and shortterm changes (Mein et al., 2001). Short-term changes represent tissue responses to a single milking and are due to congestion and edema (Hamann and Mein, 1990; Mein et al., 2001; Ohnstad et al., 2007). They have been associated with teat canal openness, penetrability, and thus susceptibility to new IMI (Neijenhuis et al., 2001; Paulrud et al., 2005; Upton et al., 2016) and diminished animal well-being (Hillerton et al., 2002). Multiple researchers therefore have been investigating short-term changes using various techniques including radiography (McDonald, 1968, 1975), ultrasonography (Neijenhuis et al., 2001; Weiss et al., 2004; Ambord and Bruckmaier, 2010), thermography (Paulrud et al., 2005), a modified skin-fold caliper (Hamann and Mein, 1988; Hamann et al., 1993), and visual assessment using a standardized scoring system that is based on discoloration of the teat skin, condition of the teat base and end, and appearance of the teat orifice (Hillerton et al., 2000). Consequently, several associated factors that help explain the variability of machine milkinginduced short-term changes in teat tissue condition such as system vacuum (Gleeson et al., 2003), milking liner design (Gleeson et al., 2004), pulsation rate and ratio (Hamann and Mein, 1996), d-phase duration (Upton et al., 2016), and milking duration (Hamann and Mein, 1990) have been reported. The primary objective 
of this study, therefore, was to investigate the association of teat-end shape with visually assessed machine milking-induced short-term changes using the scoring system according to Hillerton et al. (2000).

Data from electronic on-farm milk meters that routinely measure milking characteristics have been established as measures of parlor performance (Reid and Stewart, 2007; Treichler and Reid, 2013), premilking udder preparation (Watters et al., 2012, 2015), and assessment of liner performance (Penry et al., 2016). In addition, recent case-control studies have investigated the association of milking characteristics with the risk of clinical mastitis (Guarín and Ruegg, 2016; Penry et al., 2017a). However, the association with machine milking-induced short-term changes remains to be investigated. Our secondary aim, therefore, was to study the relationship between udder-level milking characteristics and short-term changes.

This longitudinal prospective cohort study was part of a larger project that examined the association between teat characteristics and ultrasonographically assessed machine milking-induced changes in teat condition in dairy cows and was conducted between December 2015 and April 2016 at the Teaching Dairy Barn of the College of Veterinary Medicine, Cornell University (Ithaca, NY). All procedures were evaluated and approved by the Cornell University Institutional Animal Care and Use Committee (protocol no. 2015-0116). A detailed description of study animals, management, milking machine equipment and settings, and study protocol was reported previously (Wieland et al., 2018). In brief, Holstein cows were housed year-round in 2 freestall pens with sand bedding and fed a TMR consistent with National Research Council (2001) requirements. Cows received recombinant bovine somatotropin (Posilac; Elanco Animal Health, Greenfield, IN) according to label directions and were milked 3 times daily at 0400 (milking 1), 1100 (milking 2), and $1900 \mathrm{~h}$ (milking 3) in a double-10 parallel parlor (P2100; DeLaval International AB, Tumba, Sweden). The dimensions of the milking liner (Clover SR $12 \mathrm{~mm}$; DeLaval International AB) were as follows: mouthpiece bore diameter of 20.3 $\mathrm{mm}$, a barrel length of $113 \mathrm{~mm}$, and a barrel diameter (calculated as circumference/ $\pi$ ) at $75 \mathrm{~mm}$ of $22.6 \mathrm{~mm}$. The milking liner was characterized by a multisided concave barrel geometry with thin concave side walls and thick rounded barrel corners. A detailed description of milking equipment and machine settings is provided in Supplemental File S1 (https://doi.org/10.3168/jds .2018-15057). Premilking udder preparation was consistent during the study period and consisted of precleaning teats with a clean cloth towel, teat disinfection with iodine-based teat dip (Udderdine110; Boumatic,
Madison, WI), forestripping, and drying teats with a clean cloth towel, followed by milking unit attachment. The total duration of premilking tactile stimulation was approximately $20 \mathrm{~s}$, whereas preparation lag time (time spent from the first teat stripping until completion of milking unit attachment) was approximately $150 \mathrm{~s}$.

Eligible cows were randomly allocated in blocks of 8 for 4 milking sessions at 4 consecutive days. To diminish interference with the dairy's milking routine, study cows were milked 30 min before milking 2 at $1030 \mathrm{~h}$. Descriptions of teat characteristics (teat-end shape, teat length, and teat diameter) were recorded before the start of data collection. Dimensions of teat length and diameter were assessed with a digital depth gauge (SKU 303-1752; Shars Tool Co., St. Charles, IL) and a digital caliper (75-TM54006; Vernier, Beaverton, OR), respectively. Teat length was assessed from the teat base to the teat end. Teat diameter was assessed at the midpoint between the teat base and the teat end. Teat-end shape was visually assessed and classified into 1 of 3 categories as previously described (Wieland et al., 2017): pointed, flat, and round. Teat-end hyperkeratosis (HK) was evaluated $1 \mathrm{~d}$ before data collection began according to the scoring system described by Mein et al. (2001): $1=$ no callus ring present; $2=$ callus ring but no roughness present; $3=$ callus ring and roughness present, keratin fronds extending 1 to $3 \mathrm{~mm}$ from the teat orifice; $4=$ callus ring present with excessive keratin fronds extending $\geq 4 \mathrm{~mm}$ from the teat orifice. Quarter milk samples were obtained $1 \mathrm{~d}$ before the start of data collection, refrigerated at $4^{\circ} \mathrm{C}$, and analyzed for SCC using optical fluorescence (Fossomatic FC, method 972.160; AOAC International, 2012) at Dairy One Cooperative Inc. (Ithaca, NY). Linear SCS were calculated as follows: linear SCS = $\ln [(\mathrm{SCC} / 100,000) / 0.693147]+3$. Udder-level milking characteristics [total milk yield $(\mathrm{kg})$, first 15 -s milk flow rate $(\mathbf{1 5 S} ; \mathrm{kg} / \mathrm{min}), 15$ - to 30 -s milk flow rate $(\mathbf{3 0 S} ; \mathrm{kg} /$ $\mathrm{min}), 30$ - to 60 -s milk flow rate $(\mathbf{6 0 S} ; \mathrm{kg} / \mathrm{min}), 60$ - to 120-s milk flow rate $(\mathbf{1 2 0 S} ; \mathrm{kg} / \mathrm{min})$, average milk flow rate (AMF; kg/min), peak milk flow rate (PMF; kg/ min), 2-min milk yield (2MIN; $\mathrm{kg}$ ), time in low milk flow rate (LMF; s), and milking unit on time (DUR; s)] were obtained with electronic on-farm milk meters (MM27; DeLaval International AB). Supplemental Table S1 (https://doi.org/10.3168/jds.2018-15057) provides definitions for recorded milking characteristics. Cow data (parity, DIM, and projected 305-d matureequivalent milk production) were obtained from a dairy management software program (Dairy Comp 305; Valley Agricultural Software, Tulare, CA).

Machine milking-induced short-term changes in teat tissue condition (STC) were assessed visually within 
approximately $60 \mathrm{~s}$ after unit detachment according to the scoring system described by Hillerton et al. (2000). Briefly, color of the teat skin was classified as normal (score 0 ), red (score 1), blue (score 2), and not assessable due to pigmentation; condition of the teat base included no visible mark (score 0), visible mark present (score 1), and significant swelling (score 2); consistency of the teat end was scored as soft (score 0), firm (score 1 ), and wedging present (score 2); and the appearance of the teat canal orifice was classified as opening $<2 \mathrm{~mm}$ (score 0 ) and opening $\geq 2 \mathrm{~mm}$ (score 1). For subsequent analysis, STC was dichotomized as follows: STC was present if the condition of the teat base score was 2 , the consistency at the teat end score was $\geq 1$, or the teat orifice score was 1 , whereas STC was absent otherwise. Because 168/500 (33.6\%) of teats were pigmented, thus impeding the ability to consistently evaluate color of the teat skin, this characteristic was excluded from subsequent analysis. To study the association between milking characteristics and STC on the cow level, a new variable (short-term changes on the cow level; CSTC) was created. Presence of CSTC was considered if 1 or more teats were evaluated to exhibit STC as defined above, whereas CSTC was absent otherwise.

Descriptive statistics were generated using PROC MEANS and PROC FREQ in SAS version 9.4 (SAS Institute Inc., Cary, NC). For all models 3 covariance structures were tested (compound symmetry, variance components, and autoregressive order 1), and the one that resulted in the smallest pseudo-Akaike's information criterion was selected. For all multivariable models, initial univariable associations between the outcome variable and all explanatory variables were tested. All variables with a $P$-value $<0.20$ in this step were considered for inclusion in the initial model after testing for collinearity. To study the hypothesis that teat-end shape was associated with STC, a multivariable generalized linear mixed model with a logit link and a binomial distribution was fitted with PROC GLIMMIX in SAS. Quarter within cow was the unit of analysis, the binary variable STC was the outcome of interest, and cow and quarter position nested within cow were included as random effects. The following cow- and quarter-level characteristics were considered as explanatory variables in addition to teat-end shape: parity (first, second, and third or greater lactation), DIM ( $<100,100-200$, and $>200$ DIM), quarter position (front vs. hind), teat length $(\mathrm{mm})$, teat diameter $(\mathrm{mm})$, HK (absent vs. present), linear SCS, and DUR (s). Backward stepwise selection was performed until each independent variable had a $P$ value of $<0.05$. Two-way interactions between teat-end shape and all other remaining independent variables were investigated and retained in the model if $P<$
0.05. The adjusted probability (95\% CI) of STC for a hypothetical teat with pointed, flat, and round teat-end shape, respectively, was calculated with the ILINK option in the LSMEANS statement. To test the hypothesis that udder-level milking characteristics (15S, 30S, 60S, 120S, PMF, AMF, 2MIN, LMF, and DUR) were associated with CSTC, generalized linear mixed models with a logit link and a binomial distribution were fitted with PROC GLIMMIX in SAS. Cow milking observation was the unit of analysis, and the binary variable machine milking-induced CSTC was the outcome of interest. A random effect for cow was included. Nine separate generalized linear mixed models were generated, including parity, DIM, and 1 udder-level milking characteristic at a time. Two-way interactions between remaining variables were investigated and retained in the model if $P<0.05$. The model with the lowest pseudo-Akaike's information criterion was selected as the final model. The adjusted probability $(95 \%$ CI) of CSTC for a hypothetical milking observation for a cow between 100 and 200 DIM and a 15 S of 0.5 and 1.5 $\mathrm{kg} / \mathrm{min}$, respectively, was calculated with the ILINK option in the LSMEANS statement. Additionally, we investigated the association between teat-end shape and externally measured teat dimensions (i.e., teat length and teat diameter). A detailed description of the statistical analyses using general linear mixed models is provided in Supplemental File S2 (https://doi.org/10 $.3168 /$ jds.2018-15057).

A total of 128 cows were enrolled in the study. Three cows were excluded, 1 because of clinical mastitis and 2 due to excessive defensive movements during data collection; thus, a total of 125 cows were used for the final analyses. Milking characteristics from 4 milking sessions (32 milking observations) were missing because data were not recorded or transferred by the milking point controller. One milking observation was excluded because recorded data were erroneous $(\mathrm{AMF}=0 \mathrm{~kg} /$ min). Somatic cell count data from 8 cows (32 quarter milk samples) were missing. Cows were $[$ mean \pm standard deviation (SD)] $201 \pm 88$ DIM (range: 56-528 DIM) and in their first $(\mathrm{n}=47)$, second $(\mathrm{n}=33)$, third $(\mathrm{n}=21)$, fourth $(\mathrm{n}=17)$, and fifth $(\mathrm{n}=7)$ lactation. The mean \pm SD projected 305-d mature-equivalent milk production was $14,056 \pm 2,546 \mathrm{~kg}$ (range: $7,570-19,133$ $\mathrm{kg})$. The mean $\pm \mathrm{SD}$ teat length was $45.4 \pm 6.8 \mathrm{~mm}$ (range: $33.3-78.7 \mathrm{~mm}$ ). The mean $\pm \mathrm{SD}$ teat diameter was $25.6 \pm 2.5 \mathrm{~mm}$ (range: $19.7-36.3 \mathrm{~mm}$ ). The median SCC from 468 quarter milk samples was 31,000 cells/ $\mathrm{mL}$ (range: 4,000-7,851,000 cells $/ \mathrm{mL}$ ). Frequency distribution of teat-end shape and HK stratified by quarter position is provided in Supplemental Table S2 (https:// doi.org/10.3168/jds.2018-15057). Descriptive statistics 
of milking characteristics are provided in Supplemental Table S3 (https://doi.org/10.3168/jds.2018-15057). Teat-end shape was associated with teat length $(P<$ $0.0001)$ and teat diameter $(P<0.0001)$. Controlling for the effects of parity $(P=0.0001)$ and quarter position $(P<0.0001)$, teat length (least squares means \pm standard error) was $56.8 \pm 1.1,46.0 \pm 1.2$, and 49.9 $\pm 0.5 \mathrm{~mm}$ in teats with pointed, flat, and round teatend shapes, respectively, and was different among all 3 categories $(P \leq 0.009$; Supplemental Table S4, https: //doi.org/10.3168/jds.2018-15057). Controlling for the effect of quarter position $(P<0.0001)$, teat diameter was $27.5 \pm 0.4,27.2 \pm 0.5$, and $25.6 \pm 0.2 \mathrm{~mm}$ in teats with pointed, flat, and round teat-end shapes, respectively, and was different between pointed and round $(P=0.0002)$ and flat and round $(P=0.007)$ teats (Supplemental Table S5, https://doi.org/10.3168/jds .2018-15057).

Presence of STC was recorded in 594/2,000 (29.7\%) teat observations (Supplemental Table S2). A total of 1,764 observations were used for the final analysis. The final multivariable logistic regression model for the absence or presence of STC contained the following independent variables: parity $(P=0.02)$, DIM $(P=$ $0.0001)$, teat-end shape $(P=0.0007)$, quarter position
$(P<0.0001)$, HK $(P=0.049)$, linear SCS $(P=0.03)$, and DUR $(P<0.0001)$, whereas none of the tested interactions remained in the model (Table 1). The adjusted probability (95\% CI) of STC for a hypothetical teat with pointed, flat, and round teat-end shape, respectively, was $18.2 \%(5.8-44.8), 0.4 \%$ (0.06-2.4), and $11.8 \%$ (5.4-23.7). Presence of CSTC was documented in 248/500 (49.6\%) cow milking observations. A total of 467 milking observations were used for the final analysis. Supplemental Table S6 (https://doi.org/10.3168/ jds.2018-15057) depicts results from univariable regression analyses of all 9 milking characteristics (15S, 30S, 60S, 120S, PMF, AMF, 2MIN, LMF, and DUR). The multivariable regression model including $15 \mathrm{~S}$ yielded to the lowest pseudo-Akaike's information criterion and is presented in Table 2. The adjusted probability (95\% CI) of CSTC for a hypothetical milking observation of a cow between 100 and 200 DIM and 15 S of 0.5 and 1.5 $\mathrm{kg} / \mathrm{min}$ was $53.0 \%(42.8-63.8)$ and $32.9 \%(15.2-57.3)$, respectively.

In this study, teat-end shape was associated with STC such that teats with flat ends were least likely to exhibit STC compared with teats with pointed or round ends. These findings support the results reported by other investigators describing the association

Table 1. Multivariable generalized linear mixed model showing factors associated with machine milking induced short-term changes on quarter level in 1,764 observations from 125 cows

\begin{tabular}{|c|c|c|c|}
\hline Item & $\beta^{1}(\mathrm{SE})$ & $P$-value & $\mathrm{aOR}^{2}(95 \% \mathrm{CI})$ \\
\hline Parity & & 0.02 & \\
\hline 1 st & $-1.51(0.59)$ & & $0.22(0.07-0.70)$ \\
\hline 2nd & $-1.29(0.63)$ & & $0.28(0.08-0.94)$ \\
\hline$\geq 3$ rd & Referent & & - \\
\hline $\mathrm{DI} \mathrm{M}$ & & 0.0001 & \\
\hline$<100$ & $-4.17(1.13)$ & & $0.02(0.002-0.14)$ \\
\hline $100-200$ & $0.56(0.51)$ & & $1.75(0.64-4.77)$ \\
\hline$\geq 200$ & Referent & & - \\
\hline Teat-end shape & & 0.0007 & \\
\hline Pointed & $0.52(0.59)$ & & $1.68(0.53-5.31)$ \\
\hline Flat & $-3.56(0.97)$ & & $0.03(0.004-0.19)$ \\
\hline Round & Referent & & - \\
\hline Quarter position & & $<0.0001$ & \\
\hline Front & $1.12(0.20)$ & & $3.06(2.05-4.58)$ \\
\hline Hind & Referent & & - \\
\hline Teat-end hyperkeratosis ${ }^{3}$ & & 0.049 & \\
\hline Score 1 & $2.42(1.29)$ & & $11.25(0.89-141.95)$ \\
\hline Score 2 & $-0.07(0.59)$ & & $0.93(0.29-2.97)$ \\
\hline Score 3 & $-0.58(0.36)$ & & $0.56(0.27-1.14)$ \\
\hline Score 4 & Referent & & - \\
\hline Linear somatic cell score & $0.22(0.10)$ & 0.03 & $1.25(1.02-1.53)$ \\
\hline Milking unit-on time $(\mathrm{s})^{4}$ & $0.09(0.01)$ & $<0.0001$ & $1.09(1.06-1.12)$ \\
\hline \multicolumn{4}{|c|}{$\begin{array}{l}{ }^{1} \text { Linear regression coefficient. } \\
{ }^{2} \text { Adjusted odds ratio. } \\
{ }^{3} \text { Teat-end hyperkeratosis: score } 1=\text { no callus ring present, score } 2=\text { callus ring but no roughness present, score } \\
3=\text { callus ring and roughness present, keratin fronds extending } 1-3 \mathrm{~mm} \text { from the teat orifice, score } 4=\text { callus } \\
\text { ring present with excessive keratin fronds extending } \geq 4 \mathrm{~mm} \text { from the teat orifice. } \\
{ }^{4} \text { Milking unit-on time; } 1 \text { unit }=10 \mathrm{~s} \text {. }\end{array}$} \\
\hline
\end{tabular}


Table 2. Multivariable generalized linear mixed model showing factors associated with machine milking induced short-term changes in 467 milking observations from 125 cows. Cow was included as random effect

\begin{tabular}{lccc}
\hline Item & $\beta^{1}(\mathrm{SE})$ & $P$-value & $\mathrm{aOR}^{2}(95 \% \mathrm{CI})$ \\
\hline Parity & & 0.12 & \\
1st & $-0.75(0.31)$ & & $0.47(0.23-0.96)$ \\
2nd & $-0.36(0.40)$ & & $0.70(0.32-1.53)$ \\
$\geq 3 \mathrm{rd}$ & Referent & & - \\
DIM & & 0.005 & \\
$<100$ & $-2.5(0.80)$ & & $0.08(0.02-0.40)$ \\
$100-200$ & $0.15(0.31)$ & & $1.16(0.63-2.15)$ \\
$>200$ & Referent & & - \\
$15 \mathrm{~S}^{3}(\mathrm{~kg} / \mathrm{min})$ & $-0.83(0.39)$ & 0.03 & $0.43(0.20-0.94)$ \\
\hline
\end{tabular}

${ }^{1}$ Linear regression coefficient.

${ }^{2}$ Adjusted odds ratio.

${ }^{3} 15 \mathrm{~S}=$ average milk flow rate recorded in the first $15 \mathrm{~s}$ after start of milking.

between teat-end shape and machine milking-induced long-term changes (i.e., teat-end callosity; Neijenhuis et al., 2000), indicating that teat-end shape may be one of the factors contributing to the variability of machine milking-induced changes in teat tissue condition. Several reasons may underlie the differences in the susceptibility to STC among teats with different teatend shape. These include differences in liner fit, milk flow rate, and inherent teat tissue vulnerability. Differences in teat dimensions among teats with different teat-end shape may lead to differences in liner fit and could cause variation in mouthpiece chamber vacuum (Borkhus and Rønningen, 2003) and liner compression during the pulsation cycle d-phase. Mouthpiece chamber vacuum is associated with congestion and edema of teat tissue (Penry et al., 2017b), whereas differences in liner compression may result in insufficient relief of teat-end congestion - for example, in teats that are too short to reach the collapsing point of the milking liner (Williams and Mein, 1982). Liner fit as a function of teat-end shape has not been investigated but could play a role in STC. Cows with flat teat-end shape had higher milk flow rates (i.e., 2MIN) and shorter DUR compared with cows with pointed or round teat-end shape in a recent study (Wieland et al., 2017). The magnitude of the vacuum that is applied to the teat during milking (i.e., average claw vacuum) is a function of milking system vacuum and milk flow rate: average claw vacuum $(\mathrm{kPa})$ $=[0.97 \times$ milking system vacuum $(\mathrm{kPa})]-[1.03 \times$ milk flow rate $(\mathrm{kg} / \mathrm{min})]$; this indicates that higher milk flow rates result in lower vacuum (Bade et al., 2009). When vacuum is applied to the teat during milking, shear forces generated on the teat can create congestion and edema of teat-end tissue (Williams and Mein, 1982) such that higher vacuum levels induce more severe ede- ma (Hamann et al., 1993). It is therefore possible that the average claw vacuum and thus the vacuum at the teat ends was lower in cows with 1 or more teats with flat teat-end shape, likely due to higher milk flow rates, which in turn resulted in less congestion and edema. Differences in teat anatomy such as tissue composition and vascularization among teats with different teat-end shape may influence susceptibility to STC. Because we did not investigate quarter milk flow rates, mouthpiece chamber vacuum, or teat tissue composition and vascularization, these possible explanations remain speculative. Our data indicate that front teats were more likely to exhibit STC. A possible reason is differences in milk yield between front and hind quarters in the presence of udder-level automatic cluster remover settings. Because hind quarters have significantly higher milk yield than front quarters (Weiss et al., 2004; Tančin et al., 2006), front teats may be subject to a longer overmilking phase at the end of milking when no or little milk at low flow is harvested from their respective quarters, whereas milk flow from hind quarters may still be above the switch point of the automatic cluster remover setting. This is further supported by previous work from Tančin et al. (2006) showing that the duration of the overmilking phase (milk flow rate $<0.075$ $\mathrm{kg} / \mathrm{min}$ ) was almost double for front quarters, which has been associated with STC in previous reports (Hillerton et al., 2000; Mein et al., 2001; Paulrud et al., 2005). Our results show that HK was associated with STC. Teats with either no callus formation (score 1) or excessive HK (score 4) were more likely to exhibit STC compared with teats with score 2 or 3 . Similar to our findings, previous researchers (Rathore, 1977; Bakken, 1981) reported an association between teat-end shape and machine milking-induced long-term changes (i.e., HK), with teats with a flat teat end having a lower degree of HK compared with pointed and round teats. These reports and the results of our study suggest an interrelationship between teat-end shape, STC, and HK. However, a temporal relationship between the observed machine milking-induced short- and long-term changes on teat tissue cannot be determined in this study. Teats from quarters with higher linear SCS were more likely to exhibit STC in the current study. One possible explanation is differences in milk production and milk flow curves between quarters with different linear SCS. The negative association between SCC and milk production at the quarter level has been reported in several studies (Schultz, 1977; King, 1978; Tančin et al., 2007). This may have led to overmilking, as observed by others (Tančin et al., 2007), which in turn may have resulted in more congestion and edema (Hil- 
lerton et al., 2000; Mein et al., 2001; Paulrud et al., 2005). Differences in milk flow curves were reported in a recent study (Zecconi et al., 2018), indicating that frequency of bimodal milk flow curves is higher in cows with chronic mastitis $(\mathrm{SCC}>400,000$ cells $/ \mathrm{mL}$ in the last 2 monthly records) compared with healthy cows or cows receiving a nonsteroidal anti-inflammatory drug. Bimodal milk flow curves have been reported to lead to congestion and subsequent edema of the teat tissue (Bruckmaier et al., 1995) and could further explain the observed differences. Finally, our results show that an increase in DUR increased the likelihood of STC. A positive correlation between DUR and STC after machine milking has also been suggested by Hamann and Mein (1990). The authors hypothesized this to be due to a cumulative effect of vacuum-induced strain in the teat wall yielding to dilation of blood vessels (i.e., congestion) and perivascular tissue (i.e., edema).

The second objective of our study was to investigate the association between udder-level milking characteristics and machine milking-induced short-term changes. Our results from univariable analyses show that all milking characteristics except $120 \mathrm{~S}$ and LMF were associated with CSTC. The most parsimonious multivariable model included $15 \mathrm{~S}$ and indicated that high $15 \mathrm{~S}$ is associated with lower risk of exhibiting STC of 1 or more teats after machine milking. The reason for the linear relationship found between 15S and CSTC is most likely the vacuum at the teat end (i.e., average claw vacuum) in cows with different milking characteristics as previously described (Bade et al., 2009). In the presence of consistent milking machine settings and premilking udder preparation, cow characteristics such as teat-end shape and milkability are likely to play a role in the interactive effects of milking characteristics and machine milking-induced short-term changes. Because teat-end shape differed between quarters within cows in the current study population, teat-end shape was not included in the analyses explaining the variability of machine milking-induced short-term changes on the cow level. Therefore, more work is needed investigating the interactive effects between milking characteristics, teat-end shape, and machine milking-induced short-term changes as well as the relationships between milking routine, milking characteristics, and short-term changes.

As outlined by Treichler and Reid (2013), significant numerical differences in $15 \mathrm{~S}$ exist among milk meters from different dairy equipment manufacturers. Other factors that should be taken into consideration when comparing $15 \mathrm{~S}$ among dairy farms are the pace with which the milking unit is attached after initiation of milking (Treichler and Reid, 2013), the definition of the start of milking (i.e., push of start button vs. presence of claw vacuum), and the distance between the milking cluster and the milk meter. A limitation in the current study is the fragmented consideration of milk flow curves without regard to their complex nature. In particular, disregarding the relationship of $30 \mathrm{~S}, 60 \mathrm{~S}$, and $120 \mathrm{~S}$ may result in failure to detect bimodal milk flow curves.

It is possible that the study procedures had an influence on the observed results, which may help explain the relatively low total milk yield and milk flow rates as well as the high proportion of documented STC during data collection. However, we believe that a possible influence was evenly distributed among all levels of explanatory variables. All study animals were exposed to the same milking routine and machine settings that were kept consistent throughout the study duration. Thus, individual udder or teat characteristics most likely account for the greatest variability in STC. However, we cannot preclude that results may have been influenced by the specific milking liner or machine settings chosen in this study (i.e., it is possible that the observed results are valid for the specific milking liner type only). Different machine settings or a different milking liner may have led to different results.

In the current study, teat-end shape was associated with STC such that teats with flat teat-end shape were least likely to exhibit STC. We believe that differences can be attributed mostly to the variation in anatomical dimensions and structures among teats with different teat-end shape resulting in differences in milk flow and liner fit, which in turn may have led to differences in mouthpiece chamber vacuum, vacuum at the teat end, and liner compression at the teat end. To a smaller extent, differences could have been due to differences in teat tissue composition and vascularization, which may influence the susceptibility of teats to STC during machine milking. There was a relationship between milking characteristics and CSTC such that high $15 \mathrm{~S}$ was associated with lower risk of CSTC. Incremental milk flow rates may have the potential to monitor machine milking-induced changes in teat tissue condition during individual milking sessions on a daily basis; however, more work is needed to evaluate this hypothesis and identify which of the numerous milking characteristics solely or in combination are most applicable and to establish thresholds that will serve as on-farm guidelines. Future studies should further investigate the interactive effects between milking machine settings, premilking udder preparation, and cow characteristics that help explain differences in the susceptibility of teats with different teat-end shape to STC on the quarter level. Such work has the potential to improve milking effi- 
ciency and alleviate adverse effects of machine milking on teat tissue condition.

\section{ACKNOWLEDGMENTS}

This project was supported by the Clinical Fellowship Program from Cornell University College of Veterinary Medicine (Ithaca, NY). The authors thank the staff at the Cornell Teaching Dairy Barn (Ithaca, NY). We also thank Jaclyn Marie Melvin and Anne Borkowski (Cornell University, Ithaca, NY) for their invaluable assistance with data collection. This project was financially supported by DeLaval International AB (Tumba, Sweden). Any opinions, findings, and conclusions revealed in this publication are those of the authors and do not necessarily reflect the position of the company.

\section{REFERENCES}

Ambord, S., and R. M. Bruckmaier. 2010. Milk flow-dependent vacuum loss in high-line milking systems: Effects on milking characteristics and teat tissue condition. J. Dairy Sci. 93:3588-3594. https: //doi.org/10.3168/jds.2010-3059.

AOAC International. 2012. Official Methods of Analysis. 19th ed. AOAC International, Arlington, VA.

Bade, R. D., D. J. Reinemann, M. Zucali, P. L. Ruegg, and P. D. Thompson. 2009. Interactions of vacuum, b-phase duration, and liner compression on milk flow rates in dairy cows. J. Dairy Sci. 92:913-921. https://doi.org/10.3168/jds.2008-1180.

Bakken, G. 1981. Relationships between udder and teat morphology, mastitis and milk production in Norwegian Red cattle. Acta Agric. Scand. 31:438-444. https://doi.org/10.1080/00015128109435725.

Borkhus, M., and O. Rønningen. 2003. Factors affecting mouthpiece chamber vacuum in machine milking. J. Dairy Res. 70:283-288. https://doi.org/10.1017/S0022029903006253.

Bruckmaier, R. M., E. Rothenanger, and J. W. Blum. 1995. Milking characteristics in dairy cows of different breeds from different farms and during the course of lactation. J. Anim. Breed. Genet. 112:293-302. https://doi.org/10.1111/j.1439-0388.1995.tb00569.x.

Gleeson, D. E., E. J. O'Callaghan, and M. Rath. 2003. Effect of vacuum level on bovine teat-tissue and milking characteristics. Ir. J. Agric. Food Res. 42:205-211.

Gleeson, D. E., E. J. O'Callaghan, and M. V. Rath. 2004. Effect of liner design, pulsator setting, and vacuum level on bovine teat tissue changes and milking characteristics as measured by ultrasonography. Ir. Vet. J. 57:289-296. https://doi.org/10.1186/2046 $-0481-57-5-289$.

Guarín, J. F., and P. L. Ruegg. 2016. Short communication: Pre- and postmilking anatomical characteristics of teats and their associations with risk of clinical mastitis in dairy cows. J. Dairy Sci. 99:8323-8329. https://doi.org/10.3168/jds.2015-10093.

Hamann, J., and G. A. Mein. 1988. Responses of the bovine teat to machine milking: Measurement of changes in thickness of the teat apex. J. Dairy Res. 55:331-338. https://doi.org/10.1017/ S0022029900028582.

Hamann, J., and G. A. Mein. 1990. Measurement of machine-induced changes in thickness of the bovine teat. J. Dairy Res. 57:495-505.

Hamann, J., and G. A. Mein. 1996. Teat thickness changes may provide biological test for effective pulsation. J. Dairy Res. 63:179-189.

Hamann, J., G. A. Mein, and S. Wetzel. 1993. Teat tissue reactions to milking: Effects of vacuum level. J. Dairy Sci. 76:1040-1046. https: //doi.org/10.3168/jds.S0022-0302(93)77432-9.

Hillerton, J. E., I. Ohnstad, J. R. Baines, and K. A. Leach. 2000. Changes in cow teat tissue created by two types of milking cluster. J. Dairy Res. 67:309-317.
Hillerton, J. E., J. W. Pankey, and P. Pankey. 2002. Effect of overmilking on teat condition. J. Dairy Res. 69:81-84.

King, J. O. 1978. Cell counts and composition of bovine milk. Vet. Rec. 103:397-398.

McDonald, J. S. 1968. Radiographic method for anatomic study of the teat canal: Observations on 22 lactating dairy cows. Am. J. Vet. Res. 29:1315-1319.

McDonald, J. S. 1975. Radiographic method for anatomic study of the teat canal: Changes between milking periods. Am. J. Vet. Res. $36: 1241-1242$.

Mein, G. A., F. Neijenhuis, W. F. Morgan, D. J. Reinemann, J. E. Hillerton, J. R. Baines, I. Ohnstad, M. D. Rasmussen, L. Timms, J. S. Britt, R. Farnsworth, N. Cook, and T. Hemling. 2001. Evaluation of bovine teat condition in commercial dairy herds: 1 . Noninfectious factors. Pages 347-351 in Proc. 2nd International Symposium on Mastitis and Milk Quality. National Mastitis Council Inc., Vancouver, BC, Canada.

National Research Council. 2001. Nutrient Requirements of Dairy Cattle. 7th rev. ed. Natl. Acad. Press, Washington, DC.

Neijenhuis, F., H. W. Barkema, H. Hogeveen, and J. P. Noordhuizen. 2000. Classification and longitudinal examination of callused teatends in dairy cows. J. Dairy Sci. 83:2795-2804. https://doi.org/10 .3168/jds.S0022-0302(00)75177-0.

Neijenhuis, F., G. H. Klungel, and H. Hogeveen. 2001. Recovery of cow teats after milking as determined by ultrasonographic scanning. J. Dairy Sci. 84:2599-2606. https://doi.org/10.3168/jds.S0022 -0302(01)74714-5.

Ohnstad, I., G. A. Mein, J. R. Baines, M. D. Rasmussen, R. Farnsworth, B. Pocknee, T. Hemling, and J. E. Hillerton. 2007. Addressing teat condition problems. Pages 188-199 in Proc. Natl. Mastitis Council Ann. Mtg., San Antonio, TX. Natl. Mastitis Council Inc., Madison, WI.

Paulrud, C. O., S. Clausen, P. E. Andersen, and M. D. Rasmussen. 2005. Infrared thermography and ultrasonography to indirectly monitor the influence of liner type and overmilking on teat tissue recovery. Acta Vet. Scand. 46:137-147.

Penry, J. F., P. M. Crump, P. L. Ruegg, and D. J. Reinemann. 2017a. Short communication: Cow- and quarter-level milking indicators and their associations with clinical mastitis in an automatic milking system. J. Dairy Sci. 100:9267-9272. https://doi.org/10.3168/ jds.2017-12839.

Penry, J. F., S. Leonardi, J. Upton, P. D. Thompson, and D. J. Reinemann. 2016. Assessing liner performance using on-farm milk meters. J. Dairy Sci. 99:6609-6618. https://doi.org/10.3168/jds.2015 -10310 .

Penry, J. F., J. Upton, G. A. Mein, M. D. Rasmussen, I. Ohnstad, P. D. Thompson, and D. J. Reinemann. 2017b. Estimating teat canal cross-sectional area to determine the effects of teat-end and mouthpiece chamber vacuum on teat congestion. J. Dairy Sci. 100:821-827. https://doi.org/10.3168/jds.2016-11533.

Rathore, A. K. 1977. Teat shape and production associated with opening and prolapse of the teat orifice in Friesian cows. Br. Vet. J. 133:258-262

Reid, D. A., and S. Stewart. 2007. Using electronic data to monitor and improve parlor performance. Pages $12-17$ in Proc. Natl. Mastitis Council Ann. Mtg., San Antonio, TX. Natl. Mastitis Council Inc., Madison, WI.

Schultz, L. H. 1977. Somatic cell counting of milk in production testing programs as a mastitis control technique. J. Am. Vet. Med. Assoc. 170:1244-1246.

Tančin, V., A. H. Ipema, and P. Hogewerf. 2007. Interaction of somatic cell count and quarter milk flow patterns. J. Dairy Sci. 90:22232228. https://doi.org/10.3168/jds.2006-666.

Tančin, V., B. Ipema, P. Hogewerf, and J. Mačuhová. 2006. Sources of variation in milk flow characteristics at udder and quarter levels. J. Dairy Sci. 89:978-988. https://doi.org/10.3168/jds.S0022 -0302(06)72163-4

Treichler, B. K., and D. A. Reid. 2013. Review of parlor summaries from 3x herds in the United States. Pages 85-94 in Proc. Natl. Mastitis Council Ann. Mtg., San Diego, CA. Natl. Mastitis Council Inc., Madison, WI. 
Upton, J., J. F. Penry, M. D. Rasmussen, P. D. Thompson, and D. J. Reinemann. 2016. Effect of pulsation rest phase duration on teat-end congestion. J. Dairy Sci. 99:3958-3965. https://doi.org/ $10.3168 /$ jds. $2015-10466$.

Watters, R. D., R. M. Bruckmaier, H. M. Crawford, N. Schuring, Y. H. Schukken, and D. M. Galton. 2015. The effect of manual and mechanical stimulation on oxytocin release and milking characteristics in Holstein cows milked 3 times daily. J. Dairy Sci. 98:1721-1729. https://doi.org/10.3168/jds.2014-8335.

Watters, R. D., N. Schuring, H. N. Erb, Y. H. Schukken, and D. M. Galton. 2012. The effect of premilking udder preparation on Holstein cows milked 3 times daily. J. Dairy Sci. 95:1170-1176. https: //doi.org/10.3168/jds.2011-4388.

Weiss, D., M. Weinfurtner, and R. M. Bruckmaier. 2004. Teat anatomy and its relationship with quarter and udder milk flow characteristics in dairy cows. J. Dairy Sci. 87:3280-3289. https://doi.org/ 10.3168/jds.S0022-0302(04)73464-5.

Wieland, M., D. V. Nydam, and P. D. Virkler. 2017. A longitudinal field study investigating the association between teat-end shape and two minute milk yield, milking unit-on time, and time in low flow rate. Livest. Sci. 205:88-97. https://doi.org/10.1016/j.livsci .2017.09.011.

Wieland, M., P. D. Virkler, A. H. Borkowski, N. Älveby, P. Wood, and D. V. Nydam. 2018. An observational study investigating the association of ultrasonographically assessed machine milking-induced changes in teat condition and teat-end shape in dairy cows. Animal. https://doi.org/10.1017/s1751731118001246.

Williams, D. M., and G. A. Mein. 1982. Review: Physical and physiological factors affecting milk flow rate from the bovine teat during machine milking. Pages 42-74 in Proc. Conference on Dairy Production from Pasture, Hamilton, New Zealand. K. L. Macmillan and V. K. Taufa, ed. New Zealand Society of Animal Production, Hamilton, New Zealand.

Zecconi, A., S. Frosi, M. Cipolla, and C. Gusmara. 2018. Effects of chronic mastitis and its treatment with ketoprofen on the milk ejection curve. J. Dairy Res. 85:50-52. https://doi.org/10.1017/ S0022029917000863. 